Article

\title{
The Making of a Modern Self: Vietnamese Women Experiencing Transnational Mobility at the China-Vietnam Border
}

\author{
Pengli Huang ${ }^{1,2}$ \\ ${ }^{1}$ College of Ethnology and Sociology, Guangxi University for Nationalities, Nanning, China; E-Mail: pengli305@hotmail.com \\ 2 Department of Social Work, Nanning Normal University, Nanning, China
}

Submitted: 18 November 2019 | Accepted: 8 April 2020 | Published: 28 April 2020

\begin{abstract}
China-Vietnam marriages attract increasing public attention in China and trigger many discussions on the phenomenon of 'Vietnamese brides.' The discussions are often linked to the rapid modernization of the border areas since the 1990s, caused by the re-opening of the border, the prosperity of the transnational economy and the increase of cross-border mobility between the two countries. Guided by the qualitative research paradigm, 30 Vietnamese women in cross-border intimate relationships with Chinese men were interviewed to examine their motivation and their experience of transnational mobility at the China-Vietnam border. By challenging the popular image of Vietnamese women as pitiable and ignorant country bumpkins in public discourse, this study acknowledges that these women, like other modern women, have the capacity to imagine and desire, to make decisions and to act, caring a lot about self-development and expression. Comparably, these women may not be able to enjoy the relatively rich resources and capital like the economic elites, but they have strategically manipulated multifaceted and contradictory realities at the specific context of the China-Vietnam border to better their economic circumstances, and to reshape their personal, familial, and social relationships.
\end{abstract}

\section{Keywords}

borderland; cross-border intimacy; emancipation; migration; Vietnamese brides; women

\section{Issue}

This article is part of the issue "Left Behind? Women's Status in Contemporary China" edited by Robert Walker (Beijing Normal University, China) and Jane Millar (University of Bath, UK).

(C) 2020 by the author; licensee Cogitatio (Lisbon, Portugal). This article is licensed under a Creative Commons Attribution 4.0 International License (CC BY).

\section{Introduction}

Beginning the research on Vietnamese brides, I was often asked if I thought Vietnamese women were 'modern women,' in what ways can they be defined as modern women, and how are their experiences of modernity different from modern women in Hong Kong, Shanghai, Paris, and New York, for example.

At the time, most literature I read about Vietnamese brides considered them as 'traditional' and 'lagging behind' women who seemed to be incompatible with modern societies. Particularly, in Chinese mainstream media, there was never a lack of negative news and reports about Vietnamese brides. In terms of these pitiable and ignorant images in public discourses, there was an ambivalence in imagining these Vietnamese brides as modern women. However, with the development of my fieldwork, I began to discover answers to above-mentioned questions.
The Vietnamese women I have met and interviewed are modern women, but they experience their modernity through different ways and means. We cannot use one standard to measure all 'modern' women. For urban and educated women in cosmopolitan cities, transnational travelling is an ordinary practice. Whereas for many Vietnamese women from poor and remote mountainous villages, border crossing can be a very modern and challenging endeavour. Therefore, how my research informants experience modernity differently and make themselves modern women through cross-border mobility becomes the main theme of this article.

\section{Women on the Move}

With the growing mobility in Asia over the last decade, transnational migration for marriage and employment has become a major social phenomenon. According to 
Wang and Hsiao (2009, p. 2), "the global economic restructuring in this region contributed to the influxes of migrant workers. Increasing contacts between local citizens and foreign nationals were also to result in cross-border marriage." However, as Constable (2006, p. 3) argues:

Of course poor women will want to move from a poor or 'backwards' country to work for or marry a richer person in a more 'modern' country. The structural inequality of such a situation provides a common and readily accepted logic for the growing pattern for female labor and marriage migration. This logic is not necessarily wrong, but it is not the only way to tell and understand the story.

In global marriage markets, both China and Vietnam as bride-sending countries are quite noticeable (Constable, 2005; Freeman, 2005; Wang, 2007). However, academia has shown a lack of concern about the emergence of cross-border mobility and marriage between China and Vietnam (Grillot, 2012; Huang \& Ho, 2016a, 2016b). This mobility and these marriages, in many ways, have challenged the idea of a linear and one-way migration from less developed to more developed countries. There is therefore an urgent need for scholars to take note of this new development and contribute to the existing literature on labour and marriage migration.

The reconfiguration of gendered identities associated with mobility is particularly significant, yet often overlooked (Kim, 2011; Martin, 2013). In post-reform China, the capacity to be geographically mobile is represented as a value connected with both national modernization and personal success (Lyttleton, Deng, \& Zhang, 2011). Thus, individuals' conscious awareness and valuation of their own mobility can have significant consequences for their (re)configuration of identity (Martin, 2013). The geographic proximity, relatively low cost and risk in crossing the border, and the rapid development of trade and tourism have made mutual and circular mobility between China and Vietnam familiar to many Vietnamese women. The topic of how cross-border mobility has informed new ways of self-making and how the Vietnamese women's mobility is gendered deserves more research attention.

Giddens's optimism with regard to the increased choices available to women is well illustrated in his book The Transformation of Intimacy within which women are portrayed as the "emotional revolutionaries of modernity" (Giddens, 1992, p. 130). However, in reality, not only Giddens' de-traditionalization thesis but also his observation that women can enjoy more 'choices' and 'freedoms' in late modernity are problematic. In late modernity, the construction of ideals of femininity and women's agency in forging a sense of modern selfhood is associated with women's social positioning within a particular locale (Jackson, Liu, \& Woo, 2008; Rofel, 2007).
At present, even the previously remote and underdeveloped regions show certain characteristics of a globalized neoliberal ethos (Lyttleton et al., 2011), and the China-Vietnam border is no exception. The increase of movement in the borderlands is driven by the desire to access the concrete fruits of modernization. Over time, sustained mobility and rapid expansion in border trade have resulted in stronger networks and more work choices at the China-Vietnam border. The movement at the China-Vietnam border is bidirectional with some differences: More Vietnamese people come to China for work whereas Chinese people go to Vietnam especially for tourism. Since the mid-2000s, the original trafficking discourses have mostly been replaced by growth in free movement of labour and marriage (Chan, 2013). In the borderlands, "what were once tales of deprivation and subjugation of the border have been refigured as compelling narratives of personal gain" (Lyttleton et al., 2011, p. 325).

Mobility plays a central role in shaping the kind of subjectivities migrant women desire and work toward. With the rise of women's transnational mobility, patterns of gendered social life are shifting in Asian societies (Constable, 2014; Kim, 2011; Martin, 2013). Under the new circumstances, it requires a different understanding of the ways that migrant women construct their identities and the "cultural representation and alternative space which may be less dominant and less visible in the mainstream popular imagination" (Kim, 2011, p. 37). The purpose of the article hence arises: to present how the Vietnamese women experience modernity and their transnational ventures. In particular, this article offers a discussion of how Vietnamese women's extended experiences of mobility at the China-Vietnam border may shape available opportunities and limit their choices and freedoms, and how these women's self-making journey is a gendered and reflexive process fraught with new possibilities and constraints.

\section{Research Background}

The main fieldwork was carried out in the year of 2011 and 2012. Altogether, I interviewed 30 Vietnamese women (pseudonyms have been used throughout the article in order to protect informants' privacy) in different types of cross-border intimate relationships, all of whom had met or married their Chinese partners after the re-opening of the border in 1991. The majority lived and worked in China and most had moved towards their husband. Although many of these women kept moving back and forth over the border before and after their marriages, about three quarters of the informants spent more time in China during the interview period. Some women who first migrated for job opportunities and then married Chinese men, and others migrated for marriage. Some registered their marriages, but others did not; some lived in cities while others lived in villages; and some resided on the Chinese side of the bor- 
der and others on the Vietnamese side. The situation of Vietnamese women even varied from case to case for those who lived in the same community.

The research site of this article is located at Nanning/the Friendship Port/Hanoi economic corridor, one of the economic corridors between China and Vietnam. Along this economic corridor, Nanning is the capital city of Guangxi Province, and Hanoi is the capital of Vietnam and also the central city of Northern Vietnam. This economic corridor is the most convenient way to travel between the two countries. There is an expressway to connect Nanning and Hanoi and it takes only about four to five hours by bus between the two cities. Many special policies for cross-border trade and businesses, tourism and communications have been implemented along the economic corridor. Border Trade Zones and Tax-Reservation Zones have been built along the border. The situations of 'in-between-ness' (Bao, 2005; Lyons \& Ford, 2008) or liangguo yicheng (two countries, one city) are quite apparent in these areas. Within the border zones, traders and businessmen from both countries are able to invest and carry out economic activities directly, and cross-border mobility-such as for work, tourism, education, marriage, and family visiting-is common.

Along the economic corridor, Nanning and Hanoi were the main locations where I collected data on crossborder migration and intimacy. Another important research site comprised several Border Trade Zones and neighbouring villages around the Friendship Port. The Border Trade Zones were once villages along the border that were developed into special economic areas. Many local people worked returning but others more for only going.

The research design went beyond the narrow focus on unregistered cross-border marriages and the 'mono-site' ethnography conducted by many Chinese researchers. The development of the borderlands is proceeding in an unsystematic manner and the administrations there are very disorganized. While the existing geographic/reginal divisions have been set up for the purpose of official administration, increasing national and transnational mobility has blurred the boundaries such that cross-border mobility and intimate encounters occur at various 'contact zones.' Although location is influential, it does not tell the whole story. Therefore, I travelled to different border cities, towns, trade zones, and villages to meet Vietnamese women and tried to identify varied cross-border intimacies.

I took note of any possible sources of information concerning the research topic and the travelling was often triggered by the new information acquired during the interview process; I found that many Vietnamese women repeatedly moved backwards and forwards across the border, adopting diverse strategies to adjust to or resist border control policy. Unlike the single-direction migration described by many Chinese scholars, frequent border crossing was not only a life reality but also a survival and development strategy for many Vietnamese women.

\section{Findings and Analyses}

\subsection{The Making of 'Enterprising Self'}

\subsubsection{The Lures of Mobility to the Borderland}

Now the border is much more open than before, and there are also many money-earning opportunities. As the old saying goes, kaoshan chishan, kaoshui chishui [living upon mountain when being near to the mountain; living upon water when being near to the water]. So we border residents will also take advantage of the border for living. In the past, lives of border residents here were similar to each other. With the development of the border, some people earn big money through doing cross-border business. No one can resist the temptation of being rich and people rush to the border for their dreams. If you look around, you'll see that the borderland is filled with people who come here from everywhere. I don't dare to say I am cleverer than others, but at least I am not a stupid woman. I did not expect to yiye baofu [get rich overnight] and would be satisfied with some money. What I need is chances and I always believe that my chances are the borderland here. (Simei, 34, family business)

Life is too hard and too poor to be a farmer, so many rural people have preferred to dagong [become migrant workers]. Of course, I was able to search for jobs in the cities like other migrant workers in Vietnam. However, people like us coming from the countryside without much education and skills cannot find a good job in the cities. People all want to earn big money, but to achieve this end needs guanxi [certain kinds of relational capital carrying particular cultural and social importance], capital and benshi [personal capability]. I don't have all these, and I can only depend on my hard work. I can earn a better price for my hard work in China; the income on the Chinese side almost doubles what I can make in Vietnam. In addition, due to the price differences and geographic proximity at the borderland, I am able to earn a higher income in China and then consume in Vietnam so as to save money. (Liuyi, 47, manual work)

Now the China-Vietnam border is in a golden development time, and there are so many opportunities here and also the need for a large labour force. I came to the border not just because it is easier to find a job here, but I also wanted to learn and improve my Mandarin. The potential of cross-border trade is huge; however, if you want to grasp the shangji [business opportunities], you must be familiar with both markets. The borderland is like an experimental base for testing opportunities. To hundehao [make a good life] here, you need to master bilingual fluency. If you are bilingual speaker, you will be quite popular in the labour market and can easily access more profitable 
jobs and acquire more income sources. (Ayong, 23, family business)

In those narratives, there is a key link between the 'enterprising subject' (Lyttleton et al., 2011) and the strong desire for development. At the periphery of the ChinaVietnam border, Vietnamese women also join in these modernization projects and share local discourses in terms of what constitutes personal success based on a number of facilitating factors. First, the rapid development of the border ("the potential of cross-border trade is huge") and the relatively low cost and risk in crossing the border ("take advantage of the border for living") provides greater autonomy for them. Second, the influx of population from both China and Vietnam ("the borderland is filled with people who come here from everywhere") provides an abundance of information on finding work, organizing transport, transferring money, and forming alliances. Third, women increasingly decide, sometimes independently, to choose to be migrant workers in China ("earn a better price for my hard work in China") rather than working on the farm ("life is too hard and too poor to be a farmer"). Lastly, achieving material success is prominent ("to earn a higher income," "to make a good life") in Vietnamese brides' perception of the 'enterprising self.' Underpinning these women's narratives is the manner through which liberalizing economic structures permit the development of an 'enterprising subject,' to use Lyttleton et al.'s term (2011).

Anni is 36 years old and works as a translator in Nonghuai, a border trade zone established in 1989 on the Chinese side. She came to China in 2010. Before that, she had worked in Hong Kong for five years as a waitress in a small restaurant. Anni reflects: "Work is hard there and I cannot see any future to get promotion. Although the salary here is not very high, but the job [as translator] is much more decent and I also have more freedom." Anni has learnt to speak Mandarin and Cantonese by herself, so she is able to find job opportunities with relatively little effort. Besides, the place where she works is close to her hometown and she goes home to Vietnam very often, whereas, while working in Hong Kong, she only visited home once or twice a year. In Anni's eyes, the borderland, which used to be a remote and backward region, has now become a new land for development. "As long as people can find money and opportunities near their homes, no one wants to travel so far away from home to make a living," Anni comments.

Promoting the capacity to aspire is central to state modernization programs around the world. Particularly in many developing countries like China and Vietnam, these seeds find fertile ground as economic reforms filter throughout the rural sector. When talking about the political economy of the China-Vietnam borderlands, Chan $(2013$, p. 7) has written:

China, not the West, acts as the major source of external influence for the development of the Vietnamese borderland communities, and will continue to be relevant to the borderland people in their desire for economic development and modern life. This implies a different path for modernization studies.

\subsubsection{Evolving Dynamics of Exploitation and Stigma}

Of course the bosses like to hire us Vietnamese since they can pay lower salaries. In the labour market, Vietnamese workers' salary is one-half or one-third less than the Chinese workers'....Seldom will the Chinese bosses sign any contract with their Vietnamese employees. By doing so, they [the bosses] save the money to pay wuxian yijin [five insurances and one security payment; according to Labour Protection Law in China, the employers must sign formal contracts with employees and pay five different types of insurance and one security payment for the employees] and also get rid of the trouble of applying for working visas for the foreign workers....Sometimes it feels so unfair since you do the same work as other Chinese workers but earn less than them. (Dingxuan, 35, manual work)

Single women are easily harassed when working outside. Some very terrible Chinese men always want to zhanpianyi [physically harass you] when they hear that you are from Vietnam. I don't mean every Chinese man is bad; however, at the borderland there are so many stories about Vietnamese girls tricked by Chinese men....I have to behave myself more so as not to be considered as a buzhengjing de nüren [immoral woman]....Usually a stable relationship or marriage with Chinese men will be a good protection. (Xiaomei, 23, housewife)

Everyone coming here wants to be rich and become bosses. However, not everyone knows how to do business and become the boss. It is not even easy to get a good job for women like us. Although there are many chances in the borderland, the bosses only want to hire those young and beautiful girls. Since I am old and plain, there are certainly limited chances for me.... speak mostly tuhua [a local Chinese dialect, different from both Mandarin and Vietnamese, mostly spoken by Zhuang people] and it also leaves me at a disadvantage in the labour market since the bosses want to hire those who can speak Mandarin and Vietnamese. It is too late for me to learn a new language well. (Lushi, 47, farmer)

Today, there are growing numbers of women making a living through moving. However, being migrant workers is considered to render the women's working self ("salary is one-half or one-third less") and sexual life vulnerable ("single women are easily harassed"). Sexual dangers are central to horror stories told about women concerning cheating (Vietnamese girls tricked by Chinese men") and 
stigma ("considered as an immoral woman"). Hayami (2003) also notes in her study that migrant girls from rural areas to the cities in Thailand are always strongly associated with the degeneration of morals. Due to their lack of resources to negotiate, many women have to make compromises though they aware of the inequalities ("do the same work but earn less"). Men would justify sexual harassment as these are women from a poorer country, so they can be easily accessed ("when they hear that you are from Vietnam"). To be rid of harassment thus becomes women's own responsibility ("behave myself more"). At the same time, older and notgood-looking women are excluded from the labour market ("the bosses only want to hire those young and beautiful girls"), which in another way indicates the tendency of sexualizing women' bodies. Although mobility brings new opportunities to women, it can generate new pressures to defend their capability and reputation.

\subsection{More Than Just Marriage}

\subsubsection{Marriage Migration as an Empowering Strategy}

In my village, girls usually get married at a young age. Some did it as young as fifteen or sixteen years old. Getting married at the age of eighteen or nineteen was more common. After my graduation from high school, my grandmother began to push me to get married. For her, the biggest thing in a woman's life is to get marriage and to have children. She worried that I would go wild if going to work outside.... I did not want to get married that early like my mother who got married under the arrangement of family and stayed in the village for her whole life as a farmer. I also did not like those men in the village who are loitering around all day long but doing nothing to support the families.... When I worked in China, my parents arranged several matchmakings for me in the village, but I did not agree to come back. I met my current husband at work, and we are quite compatible. (Ayong, 23, family business)

My [Vietnamese] ex-husband had an affair and later divorced me and left the daughter with me. In my village, divorce is still a very disgraceful thing, particularly for women. The bad news goes very quickly and people around nearby villages would easily know that you were a divorced woman. It was nearly impossible for me to remarry. I always felt that others were gossiping about me whenever I walked in the community. It seemed like a shame I could never get rid of....Marrying in China was a favourable choice for me since I was not only more marriageable but also, here, fewer people would track me down. (Axian, 55, farmer)

I was over thirty when I married my Chinese husband. I was not good-looking, thin with darker skin.
In Vietnam, women who could not marry like me are called 'a time bomb' and are also considered a big burden and shame for the parents. I was very worried and stressed, crying often at night. I thought my life would end up like those poor single women in the village. Luckily, when knowing my situation, a distant relative who also married in China helped arranging my marriage. (Lushi, age 47, farmer)

Some Vietnamese women migrate to free themselves from the cultural expectations that constrain their life choices back in the village. Yunyun's background is very different but migration nevertheless offers personal freedom that she is denied back home. She is 25 years old and comes from an ordinary family near Hanoi. Her family had to borrow money from relatives to send her to study in China. After graduating from university, Yunyun chooses to stay in China and considers there are more opportunities and higher incomes here. Marrying a Chinese man is also her target. Yunyun seems a mystery to her friends and no one knows what exactly she is doing. Although she needs to send money home very month to pay back her parents, she is free with money, renting a big apartment alone and buying many luxury clothes and bags. Yunyun never talks about her job with me and she makes it clear that she does not want to share anything about this topic. One time she mentioned that some of her friends kept asking about her job and she replied angrily: "I am a $j i$ [chick, but it also implies prostitute in Chinese], are you satisfied?"

Yunyun does not care too much about the gossip since she is away from home. "If I feel unhappy with the current situation, I can move to other places," she says. She has dated several men at the same time but only later introduces the one she would most probably marry to some of her friends. She admits that it is less possible for her to do that in Vietnam since there are so many acquaintances and friends around. In addition, it is also easy for potential boyfriends/husbands to track her down in Vietnam. While in China, Yunyun feels less disturbed by some unfavourable news about her since she is able to make up a decent image in marriage market whenever necessary.

Compared with other types of labour migration, women's marriage migration is 'moral' and 'less risky' sexually, mentally, and physically (Suzuki, 2005, p. 128). Marriage can also be used to achieve different kinds of purpose and autonomy as noted above, such as to avoid the pressure to get married at an early age and to free oneself from parental control (e.g., Ayong), to get rid of the stigma of being a divorced woman or single woman (e.g., Lushi and Axian), or to escape gender constraints and supervisions at home (e.g., Yunyun). "Gender relationships and women's social and cultural role are often products of socio-economic relations and the exercising of different power," as Chan $(2013$, p. 117) argues, and "in the borderland, with the open border and the availability of Chinese men, women have had a differ- 
ent choice of husbands. Getting married across the border has been part of women's attempt to pursue personal happiness."

\subsubsection{Marriage Migration as Stigma}

I think many migrant [Vietnamese] women choose to marry Chinese men not only out of convenience but also to avoid suspicions and rumours.... When you work in China, you cannot go home often. It is quite natural to date and marry a Chinese man. However, in my village there are always very bad words about migrant girls, and we are thought of as money-loving, immoral, or even as prostitutes. Men in the village also do not want to marry girls who have worked in China.... think these men are feudal and useless because they cannot accept a wife better than them and worry that they are not able to control their wives. (Aling, 28, office work)

Just because we are from Vietnam, we are always looked down upon as cheap-price brides. When Chinese women get married, they also ask for pinjin [dowry]. When we do the same, we are depicted as 'sold brides' or 'money seekers.' (Shixiang, 48, farmer)

In the community, I can often sense the discrimination against Vietnamese, although they don't speak out.... d don't like people talking about those 'runaway Vietnamese bride' stories in front of me as if I am a very untrustworthy woman.... Why cannot these brides run away? Many were promised to have a great husband and a good life in China before their coming. I think they ran away just because they felt cheated. If the promises were true, who would want to leave? (Shilan, 44, housewife)

I can speak both Vietnamese and Chinese very well. People cannot notice from my accent that I am from Vietnam. Although I have been married in China many years, only people in the village and some close friends know I am a Vietnamese. When I am outside, I tell others that I am a huaqiao [overseas Chinese] from Vietnam in order to avoid unnecessary trouble. (Ahua, 20, manual work)

In Le Bach, Bélanger, and Khuat's (2007) study on female returnees from China to Vietnam, they point out that in Vietnam, women's marriage to foreigners is viewed negatively: ' 'Having been to China' is a phrase that can immediately bring negative meanings such as prostitution, or money loving (which is culturally negative), and marriage to an 'outsider' (also culturally negative)" (Le Bach et at., 2007, p. 419). Chan (2005) also gives the example of a Vietnamese girl who worked as a tourist guide at the border and was dumped by her boyfriend since she did not accept her boyfriend's mother's advice to quit her job. Moreover, as Le Bach et al. (2007) find, it is difficult for returned Vietnamese brides and their children to reintegrate in their family and community in Vietnam. Again, they choose to migrate to China, and this choice becomes their major solution to deal with unfavourable realties. Though many Vietnamese brides consider their marriages and lives in China are happy, they are today still subject to stereotypical labelling and prejudices ('cheap-price brides,' 'sold brides,' or 'money seekers'). Thus, some just choose to distance themselves from people around ("I don't like people talking about 'runaway Vietnamese bride"') or to cover their identity ("I tell others that I am a Huaqiao").

\section{Discussion}

\subsection{Migrant Women as Labouring Subjects}

In seeking job opportunities in China, Vietnamese women embody their dreams and plans. They are encouraged to become enterprising subjects through self-actualizing and cross-border mobility. In the process, an individual becomes "an entrepreneur of oneself, maximizing himself or herself as 'human capital"' (Lazzarato, 2009, p. 111). Among different migrant Vietnamese women, kaozhe bianjing chi bianjing (depending on/taking advantage of the border) has been both a life reality and a development strategy. Although they come from different family backgrounds and hold different types of social capitals, the women are more or less integrated into, or take actively part in, the project of modernization.

Compared with 'elite subjects' in Ong's (2006) study, most Vietnamese women in this study can be defined as part of the 'uneducated rural masses.' However, from their narratives, we can observe similar desires to become enterprising subjects. As Rofel (2007) argues, everyone's modernity is different. Thus, experience of modernity is not a privilege only available to the social elites. The Vietnamese women's experiments with mobility in the newly developed borderland illustrate how they perceive the social changes happening around and remake a new self in a changing environment.

\subsection{Migrant Women as Sexual/Intimate Subjects}

The opening border provides the availability of Chinese men, increasing migrant women's mate selection prospects. This is particularly true for those women who find it very difficult to marry due to poverty, old age, low education, or divorce. They want to reclaim their femininities and increase their marriageability through migration. Feeling one's value as women or desired subjects enables these 'unwanted' Vietnamese women to rediscovery their femininities and redefine their gendered subjectivities.

Studies on women's migration have shown the intersection of labour relations with intimate engagements (Cheng, 2010; Lan, 2008; Lapanun, 2010). As Chan (2013, 
p. 105) writes, "intensified cross-border contacts between men and women on the two sides of the border also facilitated increasing cross-border romance, wooing games and marriage." Intimate imaginations and encounters are important in women's self-making process. Contrary to the descriptions of Vietnamese migrant women as 'trafficking victims,' 'illegal brides' or 'prostitutes' in some dominant discourses in China and Vietnam, they have taken much control of their migration and their relationships with Chinese men.

\subsection{The Making of the Modern Self and the New Gender Predicament}

The cross-border mobility of Vietnamese brides is driven by the strong desire for a better life and the wish to seize the opportunity to earn a livelihood and accumulate wealth. It echoes certain characteristics of a globalized neoliberal ethos promoted by capitalism (Ong, 2006). However, these Vietnamese women's migratory stories exemplify how their mobility is gendered. For instance, they encounter certain gender discriminations and exploitations at work, and sexual harassment or rumours of prostitution are always associated with single migrant woman. The gendered expectations of women as xianqi liangmu (virtuous wife and wise mother) serve to contain them within the domestic sphere.

While mobility creates new chances for women to challenge existing gendered norms, they still face constant criticisms and suspicion of not being a 'good woman.' Thus, to use Xiaomei's terms, they have to "behave themselves more" so as to get rid of the stigma. Although they are away from home and engage in productive activities, it does not mean that they have been freed from traditional gendered constraints. Identified by Fouron and Schiller (2001), the hierarchies based on male power can extend beyond national borders and affect migrant women in a transnational context. Thinking about the relation between gender and modernity, on the one hand, women gain new opportunities and new identities in changing contexts; on the other hand, the new selves are made through many struggles and compromises. The Vietnamese women's experiences of mobility at the China-Vietnam border reveal much more complicated pictures of modernity in terms of the new possibilities and limitations that they have encountered in their self-making projects.

\section{Conclusion}

Research on Vietnamese women is not new but academic have only recently become to focus on the experiences of Vietnamese women in China. Since I developed my research interest on this topic, there have been many substantial changes in the China-Vietnam border areas that have further complicated the lives of Vietnamese women. However, these changes have been overlooked in previous scholarship. Most discussions still focus on Vietnamese women's unregistered marriages with Chinese men. Undeniably, early in the opening of the border in the 1990s, many Vietnamese women came to China mainly for the purpose of marriages and their coming attracted public interests at a time when immigration into China was negligible.

Both China and Vietnam are emigration than immigration countries, and they also are not ready for taking more immigrants due to huge population in respective countries. Although there is more and more cross-border mobility at the border areas, it is noticeable that most people who cross border are sojourners rather than settlers, and that at present marriage immigrants only make a very small percentage of total cross-border population. Neither the government has implemented new polices to ease cross-border marriage registration (such as citizenship or hukou application processes) for marriage immigrants. This fact has affected Vietnamese women differently according to their aspirations and circumstances in China.

For those Vietnamese women who develop stable relationships with Chinese men and want to settle down in China, most of them have to accept an unregistered marriage. However, for those who do not plan to settle down, job opportunity plays a more important role than marriage. Now in the border areas, being an independent passport holder and applying for temporary work visa has been much easier than being an officially registered marriage settler. This situation means that Vietnamese women no longer need to resort to marriage as their main strategy. The prosperity of the borderland provides more and more job opportunities, thus Vietnamese women can take advantage of jingji xina (economic absorption) to circumvent the current policy of shenfen juru (identity refusal).

In the border frontier areas, geographic proximity, as well as sharing the same language, ritual, habits, and ethnicity, becomes convenient factors facilitating transnational mobility (Tran, 2017; Zhou, 2017). Vietnamese women's transnational mobility differs from that of other immigrant women in that living in the borderland enable them to move back and forth across the border for survival and development, acquiring certain mobility capitals and rights in the process. However, it does not mean that their involvements in modern development are "experiments with freedom" (Ong, 2006). Their transnational mobility is derived from the desire to access concrete fruits of modernization at the ChinaVietnam border. During the process, gender norms and ideologies can also be modernized within the changing socio-economic environments. The experience of Vietnamese women demonstrates that although mobility has brought them new opportunities to try different lives and to form new subjectivities, their project of selfmaking through migration is heavily constrained by prevailing and influential gender discourses.

When examining public debate concerning Vietnamese women in China, we can easily identify sev- 
eral themes, such as trafficking (Stöckl, Kiss, Koehler, Dung, \& Zimmerman, 2017), unregistered marriage (Ji \& Ren, 2016), commercial matching making (Wu \& Chen, 2017), and runaway bride ( $\mathrm{Wu}, 2015)$. The public discourse indicates a rather unfriendly environment for Vietnamese women. Yet, more and more Vietnamese women choose to come to China in search of opportunities. These Vietnamese women are not blind or ignorant of obvious unfriendliness; rather, the contradicted reality is a good example revealing the benefits and struggles encountered by Vietnamese women when moving to China (Huang, 2017). On the one hand, they face harsh realities in terms of their identity as women and immigrants; on the other hand, they acquire new freedom and opportunities when crossing the border and joining in development. So far, studies on Vietnamese women in China are still very rear with little known about their transitional mobility and the reality of their daily lives. Women's new immigration patterns and their gendered experiences of mobility are in need of further explorations.

\section{Acknowledgments}

This research received funding from the Guangxi Special Funded Project for Post-doc Researchers (No. BH2018090) and the Research Project on Crossborder Working People at the China-Vietnam Border (No. 2018XGDYB002).

\section{Conflict of Interests}

The author declares no conflict of interests.

\section{References}

Bao, J. (2005). Marital acts: Gender, sexuality, and identity among the Chinese Thai diaspora. Honolulu: University of Hawai'i Press.

Chan, Y. W. (2005). Vietnamese or Chinese: Viet-kieu in the Vietnam-China Borderlands. Journal of Chinese Overseas, 1(2), 217-232.

Chan, Y. W. (2013). Vietnamese-Chinese relationships at the borderlands: Trade, tourism, and cultural politics. New York, NY: Routledge.

Cheng, S. (2010). On the move for love: Migrant entertainers and the U.S. military in South Korea. Philadelphia, PA: University of Pennsylvania Press.

Constable, N. (2005). Introduction: Cross-border marriages, gendered mobility, and global hypergamy. In N. Constable (Ed.), Cross-border marriages: Gender and mobility in transnational Asia (pp. 1-16). Philadelphia, PA: University of Pennsylvania Press.

Constable, N. (2006). Brides, maids, and prostitutes: Reflections on the study of 'trafficked' women. PORTAL Journal of Multidisciplinary International Studies, 3, 1-25.

Constable, N. (2014). Born out of place: Migrant moth- ers and the politics of international labor. Hong Kong: Hong Kong University Press.

Fouron, G., \& Schiller, N. G. (2001). All in the family: Gender, transnational migration and the national state. Identities, 7(4), 539-582.

Freeman, C. (2005). Marrying up and marrying down: The paradoxes of marital mobility for Chosonjok brides in South Korea. In N. Constable (Ed.), Crossborder marriages: Gender and mobility in transnational Asia (pp. 80-100). Philadelphia, PA: University of Pennsylvania Press.

Giddens, A. (1992). The transformation of intimacy: Sexuality, love, and eroticism in modern societies. Stanford, CA: Stanford University Press.

Grillot, C. (2012). Between bitterness and sweetness, when bodies say it all: Chinese perspectives on Vietnamese women in a border space. Journal of Vietnamese Studies, 17(1), 106-148.

Hayami, Y. (2003). Reorganizing and traversing space: Women in the peripheries of Thailand. In Y. Hayami, A. Tanabe, \& Y. Tokita-Tanabe (Eds.), Gender and modernity: Perspectives from Asia and the Pacific (pp. 146-166). Kyoto and Melbourne: Kyoto University Press \& Trans Pacific Press.

Huang, P. (2017). Dependent or breadwinner? Vietnamese brides reshaping gender roles at the ChinaVietnam border. Journal of Chinese Sociology, 16 (4), 1-17.

Huang, P., \& Ho, S. Y. (2016a). Youqian jiuyou haonüer: Yuenan xinniang dui “tiebu niangjia” xingwei de jieshi [Money makes a good daughter: Vietnamese brides' explanations of sending money home]. Collection of Women's Studies, 133(1), 107-117.

Huang, P., \& Ho, S. Y. (2016b). Vietnamese brides' practices of maternal citizenship at the China-Vietnam border. Asian Women, 32(1), 77-110.

Jackson, S., Liu, J., \& Woo, J. (2008). Introduction: Reflections on gender, modernity and East Asian sexualities. In S. Jackson, J. Liu, \& J. Woo (Eds.), East Asian sexualities: Modernity, gender and new sexual cultures (pp. 1-32). London and New York, NY: Zed Books.

Ji, H., \& Ren, X. (2016). Zhongyue bianmin tonghun: Zhidu kunjing yu guojia zhili [The marriages between Chinese and Vietnamese border residents: Institutional dilemma and national governance]. Academic Exploration, 10, 70-74.

Kim, Y. (2011). Transnational migration, media and identity of Asian women: Diasporic daughters. New York, NY: Routledge.

Lan, P.-C. (2008). New global politics of reproductive labor: Gendered labor and marriage migration. Sociology Compass, 2(6), 1801-1815.

Lapanun, P. (2010). Transnational marriages of rural Isan women and the local influences. Paper presented at the Revisiting Agrarian Transformations in Southeast Asia: Empirical, Theoretical and Applied Perspectives Conference, Chiang Mai, Thailand.

Lazzarato, M. (2009). Neoliberalism in action: Inequality, 
insecurity and the reconstitution of the social. Theory, Culture and Society, 26(6), 109-133.

Le Bach, D., Bélanger, D. I., \& Khuat, T. H. (2007). Transnational migration, marriage and trafficking at the China-Vietnam border. In I. Attane \& C. Z. Guilmoto (Eds.), Watering the neighbour's garden: The growing demographic female deficit in Asia (pp. 393-426). Paris: CICRED.

Lyons, L. T., \& Ford, M. (2008). Love, sex and the spaces in-between: Kepri wives and their cross-border husbands. Citizenship Studies, 12(1), 55-72.

Lyttleton, C., Deng, R., \& Zhang, N. (2011). Promiscuous capitalism meets 'exotic' ethnicity: Intimate aspirations amongst cross-border Chinese Dai. The Australian Journal of Anthropology, 22, 314-331.

Martin, F. (2013). Transnational dream, transnational practice: Tracking women students in Asia's knowledge diasporas. Inter-Asia Cultural Studies, 14(3), 468-475.

Ong, A. (2006). Experiments with freedom: Milieus of the human. American Literary History, 18(2), 229-244.

Rofel, L. (2007). Desiring China: Experiments in neoliberalism, sexuality, and public culture. Durham, NC: Duke University Press.

Stöckl, H., Kiss, L., Koehler, J., Dung, T. D., \& Zimmerman, C. (2017). Trafficking of Vietnamese women and girls for marriage in China. Global Health Research and Policy, 2, 28-37.

Suzuki, N. (2005). Tripartite desires: Filipino-Japanese marriages and fantasies of transnational traversal.
In N. Constable (Ed.), Cross-border marriages: Gender and mobility in transnational Asia (pp. 124-144). Philadelphia, PA: University of Pennsylvania Press.

Tran, H. H. (2017). Non-agricultural activities of ethnic minorities in Vietnam-China borderland. Vietnam Social Sciences, 182(6), 76-85.

Wang, H.-Z. (2007). Hidden spaces of resistance of the subordinated: Case studies from Vietnamese female migrant partners in Taiwan. International Migration Review, 41(3), 706-727.

Wang, H.-Z., \& Hsiao, H.-H. M. (Eds.). (2009). Crossborder marriages with Asian characteristics. Taipei: Taiwan Academia Sinica, Centre for Asia-Pacific Area Studies.

Wu, Y. (2015, November 6). Yuenan xinniang pianhun, shuineng baozheng paoyige peiyige [Vietnamese brides' cheating: Who can make up the loss of runaway brides]. China Youth Daily. Retrieved from http://www.zqb.cyol.com

Wu, Y., \& Chen, H. (2017). Wuli bumei: Zhongyue kuaguo hunyin hunjiezhe de xingdong luoji [Match-making for profits: The behavior logic of commercial matchmakers in China-Vietnam marriages]. Population and Society, 33(3), 104-114.

Zhou, J. (2017). Bianjing, bianmin yu guojia: Kuaguo minzhu yanjiu de sange mianxiang [Border, border residents and nation-state: Three-dimension of cross-border ethnic studies]. Guangxi Ethnic Studies, 135(3), 1-8.

\section{About the Author}

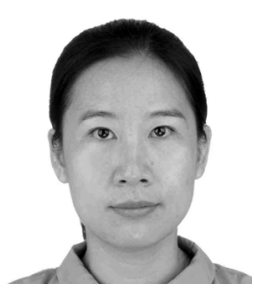

Pengli Huang is a Post-Doc Research Fellow at the Guangxi University for Nationalities and Dean of the Department of Social Work in Nanning Normal University. She got her PhD degree from the Department of Work and Social Administration at the University of Hong Kong. Before that she was a visiting scholar at the Centre for Women' and Gender Studies at the University of Texas at Austin, USA. Her research field includes migration studies and gender studies. 